\title{
COMPARATIVE STUDY OF INTRATHECAL NEOSTIGMINE AND CLONIDINE
}

Balasubramaniam Solaiappan1, Revathy Jeevarathnam²

${ }_{1}^{1}$ Associate Professor, Department of Anaesthesiology, Chengalpattu Medical College.

2 Professor, Department of Anaesthesiology, Chengalpattu Medical College.

\begin{tabular}{l}
\hline ABSTRACT \\
BACKGROUND \\
Providing good analgesia with adequate muscle relaxation during the intraoperative period and managing pain in the \\
postoperative period is a good anaesthetic practice. Effective control of postoperative pain can reduce morbidity and mortality, early \\
mobilization, patient comfort and satisfaction, less chances of deep vein thrombosis, cost and less bed occupancy. This study is \\
designed to find the effect of adding clonidine or neostigmine to $0.5 \%$ hyperbaric bupivacaine for spinal anaesthesia to achieve \\
quality regional block as well as good postoperative analgesia.
\end{tabular}

\section{AIMS}

This study is conducted to analyse the effect of adding adjuvant neostigmine $50 \mu \mathrm{g}$ or clonidine $50 \mu \mathrm{g}$ to intrathecal $0.5 \%$ hyperbaric bupivacaine and evaluating the intraoperative haemodynamic stability and total duration analgesia with each drug in patients undergoing lower abdominal and lower limb surgeries.

\section{METHODS AND MATERIALS}

The present study was carried out in the Department of Anaesthesiology, Govt. Chengalpattu Medical College, Chengalpattu, Tamilnadu in association with the Department of General Surgery, Orthopaedics and Department of Obstetrics and Gynaecology in which 90 patients of either sex of ASA grade I and II between the ages of 18 and 50 years. These patients were systematically randomized into 3 groups of 30 each, Group A - Receiving 0.5\% bupivacaine alone, Group B - Receiving $0.5 \%$ bupivacaine with 50 $\mu \mathrm{g}$ neostigmine and Group C - Receiving $0.5 \%$ bupivacaine with $50 \mu \mathrm{g}$ clonidine.

\section{STATISTICAL ANALYSIS}

The data was analysed by statistical software SPSS 17.0 for windows. Chi-square test was used to analyse categorical data.

\section{RESULTS}

Results show that intrathecal neostigmine additive has faster onset of sensory and motor blockade, but Intrathecal clonidine has longer duration of sensory and motor blockade. Intrathecal bupivacaine alone lags behind in onset as well as duration of sensory and motor blockade.

\section{CONCLUSION}

Intrathecal clonidine $50 \mu \mathrm{g}$ or neostigmine $50 \mu \mathrm{g}$ with bupivacaine is better in providing faster onset of blockade, out of which clonidine is a better adjuvant in providing good postoperative analgesia.

\section{KEYWORDS}

Intrathecal, Neostigmine, Clonidine, Spinal.

HOW TO CITE THIS ARTICLE: Solaiappan B, Jeevarathnam R. Comparative study of intrathecal neostigmine and clonidine. J. Evolution Med. Dent. Sci. 2016;5(57):3917-3925, DOI: 10.14260/jemds/2016/897

\section{INTRODUCTION}

The most commonly administered anaesthesia is the spinal subarachnoid block, as it is easy to perform as a single shot technique. When compared to epidural and general anaesthesia, the main problem of spinal anaesthesia is that the postoperative analgesia which lasts only for a brief period.

As lower abdominal and lower limb surgeries are commonly performed under spinal anaesthesia, adding adjuvant which prolong the duration of anaesthesia and provide postoperative analgesia can be beneficial. So

Financial or Other, Competing Interest: None.

Submission 28-05-2016, Peer Review 05-07-2016,

Acceptance 11-07-2016, Published 16-07-2016.

Corresponding Author:

Dr. Revathy Jeevarathnam,

No. 33/4, V. P. Colony,

North Street,

Ayanavaram

Chennai-600023.

E-mail: drparthart@gmail.com

DOI: $10.14260 /$ jemds/2016/897 adjuvants like opioids and newer adjuvants like clonidine, neostigmine and ketamine to the local anaesthetic agents have been tried with varying success rates.

Additives decrease the requirement of local anaesthetic agents. They intensify and prolong the duration of analgesia. They have synergistic action, thus decreasing the dose of drug and side effects of individual agents.

Local anaesthetics bind in the "inner vestibule" of the closed $\mathrm{Na}+$ channel and obstruct the external opening and maintains the channels in the closed inactivated state, which is not permeable to sodium, blocks the conduction of nerve impulses. Neostigmine acts on Lamina 2 substantia gelatinosa of Rolando and on lamina 3 and 4, and cause stimulation of muscarinic receptors $\mathrm{M} 1$ and $\mathrm{M} 2$.

Clonidine acts on the postsynaptic alpha 2 receptors (Stimulation) in substantia gelatinosa present in dorsal horn of the spinal cord. Clonidine also has the intrinsic property to block the conduction in $\mathrm{C}$ and $\mathrm{A}-\delta$ fibres. 


\section{AIMS AND OBJECTIVES}

To compare the use of neostigmine $50 \mu \mathrm{g}$, clonidine $50 \mu \mathrm{g}$ along with $0.5 \%$ hyperbaric bupivacaine in spinal anaesthesia in patients undergoing lower abdominal and lower limb surgeries in providing postoperative analgesia with stability of the haemodynamic status.

The objectives of this study is comparative evaluation of clonidine and neostigmine with $0.5 \%$ bupivacaine in spinal anaesthesia with respect to:

1. Onset time of sensory and motor block.

2. Duration of motor block.

3. Duration of analgesia.

4. Intraoperative haemodynamics.

5. Side effects.

\section{METHODS AND MATERIALS}

After getting the approval by the Ethical Committee, study was conducted on 90 patients who underwent lower abdominal and lower limb surgeries under spinal anaesthesia. It is a comparative prospective randomized double blind controlled study. This study was done in the Department of Anaesthesiology, Govt. Chengalpattu Medical College, Chengalpattu with the supportive help of the Obstetrics and Gynaecology, General Surgery and Orthopaedics Departments for a period of one year. Patient counselling was done and informed consent obtained.

\section{Inclusion Criteria}

1. Age $18-50$ years of both sex.

2. ASA I and II.

3. Elective lower abdominal and lower limb surgeries of $<90$ minutes' duration.

\section{Exclusion Criteria}

1. Age $<18$ years and $>50$ years.

2. ASA III and IV.

3. Hypersensitivity to bupivacaine.

4. Haemodynamic instability.

5. Infection at the lumbar puncture site.

6. Patients on anticoagulants/bleeding disorders.

7. Patient refusal.

8. Patients with neuromuscular disorders.

9. Psychiatric illness.

\section{PATIENTS WERE RANDOMLY DIVIDED INTO THREE GROUPS OF EACH}

Group A - Control group - Receiving 0.5\% bupivacaine alone. Group B - Neostigmine group - Receiving 0.5\% bupivacaine with $50 \mu$ g neostigmine.

Group C - Clonidine group - Receiving 0.5\% bupivacaine with $50 \mu$ g clonidine.

\section{Preoperative Evaluation}

Age, weight, height, vital parameters, history of previous anaesthesia and surgery, significant medical illness and medications and allergies were recorded in all patients. Complete physical examination, airway assessment followed by laboratory investigations was done.

Haemoglobin, PCV, Total WBC count, Differential WBC count, ESR, Urine albumin and sugar, Blood urea, serum creatinine, liver function tests, ECG, X-ray chest, Blood grouping and typing and other relevant investigations.

\section{METHODOLOGY}

All the patients were premedicated with Tab. Ranitidine 150 $\mathrm{mg}$ and Tab. diazepam $5 \mathrm{mg}, 2 \mathrm{hrs}$. before the spinal anaesthesia. On the day of surgery, Intravenous (IV) line with 18-G cannula was secured. Patients were connected to multiparameter monitor with Electrocardiogram (ECG), Oxygen Saturation (SPO2) and Non-Invasive Blood Pressure (NIBP) and basal readings recorded. All the patients were preloaded with $10 \mathrm{~mL} / \mathrm{kg}$ of Ringer lactate. Under sterile aseptic precautions, subarachnoid block performed with $25-\mathrm{G}$ Quincke's needle with the patient in the right lateral position.

Group A: Received $2.5 \mathrm{~mL}$ of $0.5 \%$ hyperbaric bupivacaine.

Group B: Neostigmine $(0.5 \mathrm{mg} / \mathrm{mL}) 1 \mathrm{~mL}$ is diluted up to $5 \mathrm{~mL}$ with normal saline from which $0.5 \mathrm{~mL}(50 \mu \mathrm{g})$ is added to the $2.5 \mathrm{~mL}$ of $0.5 \%$ hyperbaric bupivacaine.

Group C: Clonidine $(100 \mu \mathrm{g} / \mathrm{mL}) 0.5 \mathrm{~mL}(50 \mu \mathrm{g})$ is added to the $2.5 \mathrm{~mL}$ of $0.5 \%$ hyperbaric bupivacaine.

Vital signs were monitored at $2^{\text {nd }}$ minute and every 5 minutes till completion of the surgery. Surgery was started after adequate surgical anaesthesia was obtained. Time of completion of the surgical procedures were noted. Patients were monitored in the recovery room until there was two segment regression of sensory block. Pain was assessed using Visual Analogue Scale (Figure 1) during recovery and postoperative period. Rescue analgesia (Inj. Pethidine $50 \mathrm{mg}+$ Inj. Promethazine $12.5 \mathrm{mg}$ IM) was given at the time of perception of pain, after noting the VAS score. Motor block was assessed using modified Bromage Scale (Table 1) for both lower limbs.

\begin{tabular}{|c|c|}
\hline Score & Criteria \\
\hline 1 & Complete block (unable to move feet or knee) \\
\hline 2 & Almost complete block (able to move feet only) \\
\hline 3 & Partial block (just able to move knee) \\
\hline 4 & $\begin{array}{c}\text { Detectable weakness of hip flexion, while supine } \\
\text { (full flexion of knees) }\end{array}$ \\
\hline 5 & $\begin{array}{c}\text { No detectable weakness of hip flexion while } \\
\text { supine }\end{array}$ \\
\hline 6 & Able to perform partial knee bend \\
\hline \multicolumn{2}{|c|}{ Table 1: Modified Bromage Score as used by Breen et al } \\
\hline
\end{tabular}

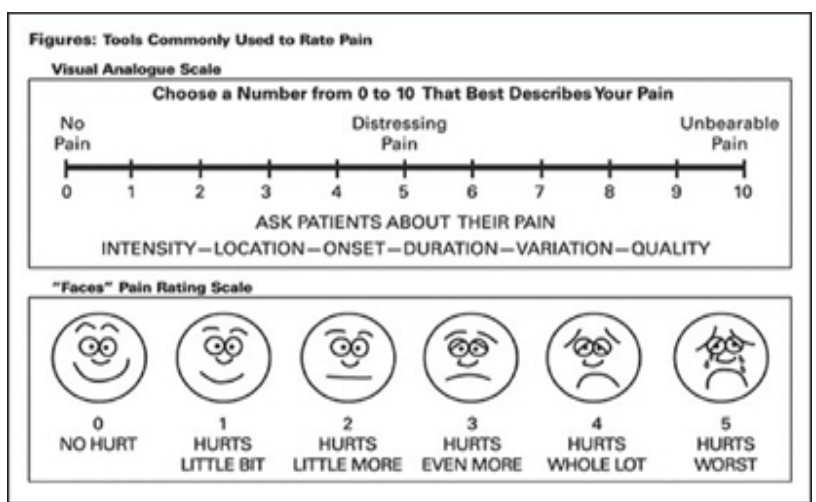

Fig. 1: Visual Analogue Scale 


\section{Parameters Noted}

1. Heart rate.

2. Non-invasive blood pressure.

3. Oxygen saturation.

4. Respiratory rate.

5. Sensory block.
a. Onset time.
b. Maximum level of block.
c. Duration.

6. Motor block.
a. Onset time
b. Duration.

7. Time of pain perception.

\section{OBSERVATION}

The following data were collected in this study.

1. Demographic profile such as age in years, sex, weight in kgs.

2. Onset time for sensory block.

3. Highest level of sensory block.

4. Onset and Duration of motor block.

5. Time for rescue analgesia (duration of analgesia) - Time of pain perception.

6. Heart rate, systolic blood pressure, diastolic blood pressure and at baseline, 2 minutes after spinal and every 5 minutes thereafter.

The duration of surgeries were noted. Postoperative analgesia was calculated from the time of end of the surgical procedure to the time of pain perception, which was assessed by Visual Analogue Scale and the VAS score was noted.

\section{STATISTICAL METHODS}

The data was analysed by statistical software SPSS (Statistical Package for Social Sciences) 17.0 for windows. Chi-square test was used to analyse categorical data.

\section{RESULTS}

The three groups were comparable with respect to the age, weight and sex. There was no statistical difference between the two groups in demographic profile (Tables 2, 3, 4; Figures $2,3,4)$.

\begin{tabular}{|c|c|c|c|c|}
\hline & Group A & Group B & Group C & P value \\
\hline Age (Mean & $41.45 \pm$ & $43.4 \pm$ & $39.15 \pm$ & \multirow{2}{*}{.489 } \\
\pm SD) & 12.458 & 8.923 & 11.811 & \\
\hline \multicolumn{5}{|c|}{ Table 2: Age Distribution } \\
\hline
\end{tabular}

\begin{tabular}{|c|c|c|c|c|}
\hline & Group A & Group B & Group C & P value \\
\hline $\begin{array}{c}\text { Weight in } \\
\text { kg (Mean } \\
\pm \text { SD) }\end{array}$ & $60.1 \pm 6.593$ & $\begin{array}{c}61.35 \pm \\
9.213\end{array}$ & $\begin{array}{c}61.25 \pm \\
7.247\end{array}$ & 0.852 \\
\hline \multicolumn{5}{|c|}{ Table 3: Weight Distribution } \\
\hline
\end{tabular}

\begin{tabular}{|c|c|c|c|}
\hline Gender & Group A & Group B & Group C \\
\hline Male & 13 & 14 & 17 \\
\hline Female & 17 & 16 & 13 \\
\hline \multicolumn{4}{|c|}{ Table 4: Gender Distribution } \\
\hline
\end{tabular}

\section{Fig 2 - Age Distribution}

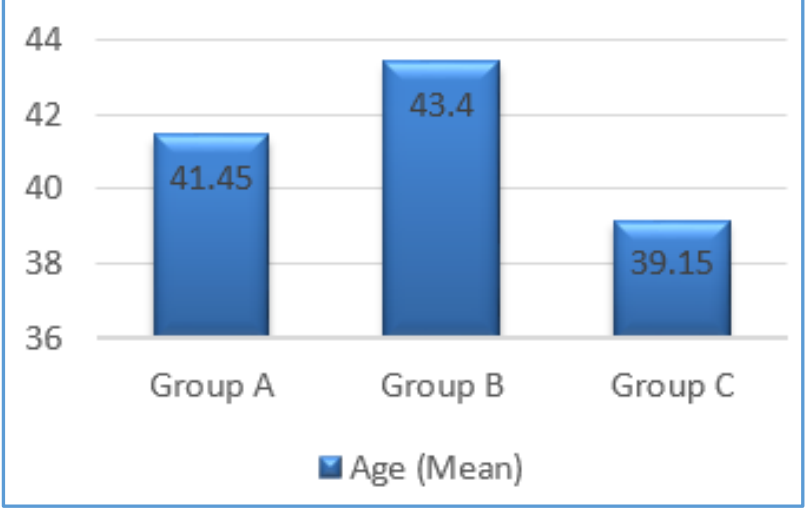

\section{Fig 3 - Weight Distribution}

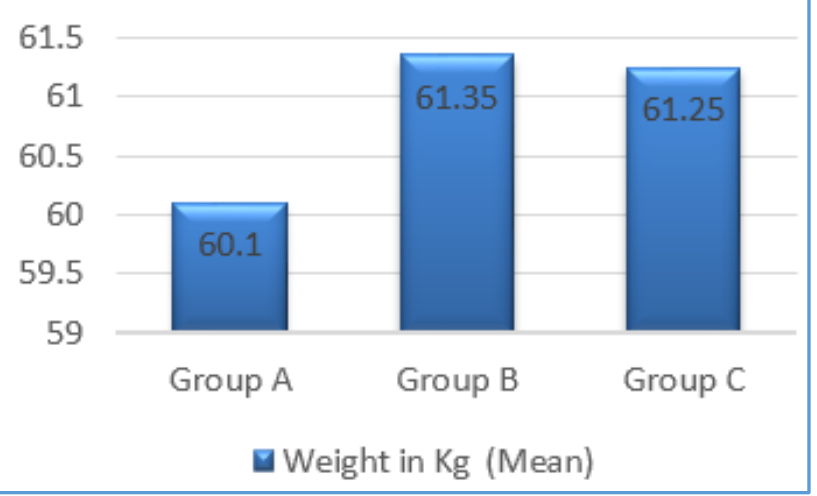

Fig 4 - Gender Distribution

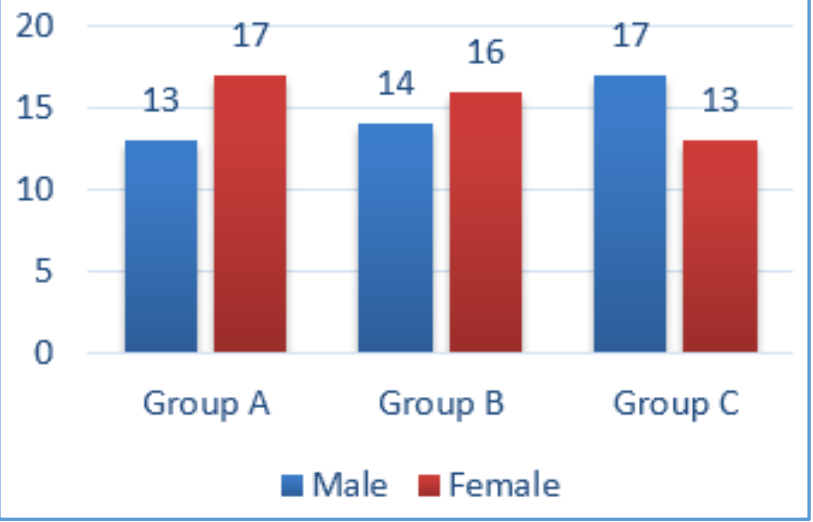

The mean onset time of sensory block (Table 5, Figure 5) in each groups were as follows. Group A is 166.2 \pm 7.824 , Group $B$ is $96.2 \pm 29.24$ and Group C is $102.75 \pm 29.99$ seconds. Onset of sensory block is faster in the neostigmine group than the other two groups. There was statistically significant difference between the three groups $(\mathrm{p}<0.0001)$.

\begin{tabular}{|c|c|c|c|c|}
\hline Onset & $\begin{array}{c}\text { Group } \\
\text { A }\end{array}$ & $\begin{array}{c}\text { Group } \\
\text { B }\end{array}$ & $\begin{array}{c}\text { Group } \\
\text { C }\end{array}$ & $\begin{array}{c}\text { P } \\
\text { value }\end{array}$ \\
\hline Sensory & $166.2 \pm$ & $96.2 \pm$ & $102.75 \pm$ & $<0.00$ \\
Block & 7.824 & 29.24 & 29.99 & 01 \\
(Seconds) & Table 5: Mean Onset of Sensory Block \\
\hline \multicolumn{6}{|c}{} \\
\hline
\end{tabular}


The maximum level of sensory block achieved was noted to be between T6 and T10. Most of the patients in the three groups were found to have block up to the T6 level (Table 6, Figure 6). There was no significant difference between the three groups $(\mathrm{p}>0.5)$.
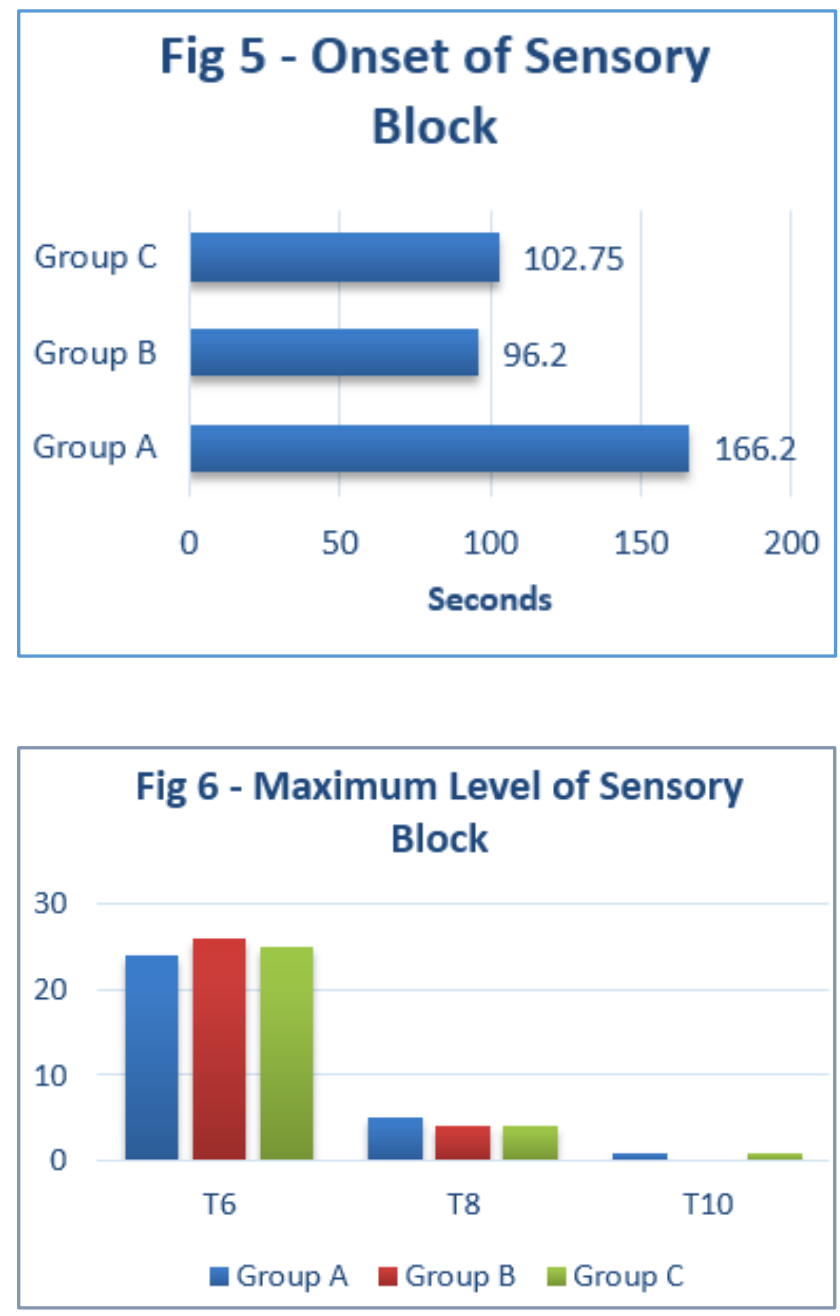

\begin{tabular}{|c|c|c|c|}
\hline Maximum Level & Group A & Group B & Group C \\
\hline T6 & 24 & 26 & 25 \\
\hline T8 & 5 & 4 & 4 \\
\hline T10 & 1 & 0 & 1 \\
\hline Table 6: Maximum Level of Sensory Block Achieved \\
\hline
\end{tabular}

The mean duration of sensory block (Table 7, Figure 7) (Time from the onset to the time of pain perception) was statistically significant in all three groups. Group A 184.32 \pm 17.16 , Group B $204 \pm 20.1$ and in Group C it is $312 \pm 37.38$ minutes. The duration was significantly longer in the clonidine group $(\mathrm{p}<0.0001)$.

\begin{tabular}{|c|c|c|c|c|}
\hline & Group A & Group B & Group C & P value \\
\hline $\begin{array}{c}\text { Sensory } \\
\text { Block } \\
\text { (min) }\end{array}$ & $\begin{array}{c}184.32 \pm \\
17.16\end{array}$ & $204 \pm$ & $312 \pm$ & $<0.0001$ \\
\hline \multicolumn{4}{|c|}{ Table 7: Mean Duration of Sensory Block } \\
\hline
\end{tabular}

\section{Fig 7 - Duration of Sensory Block}
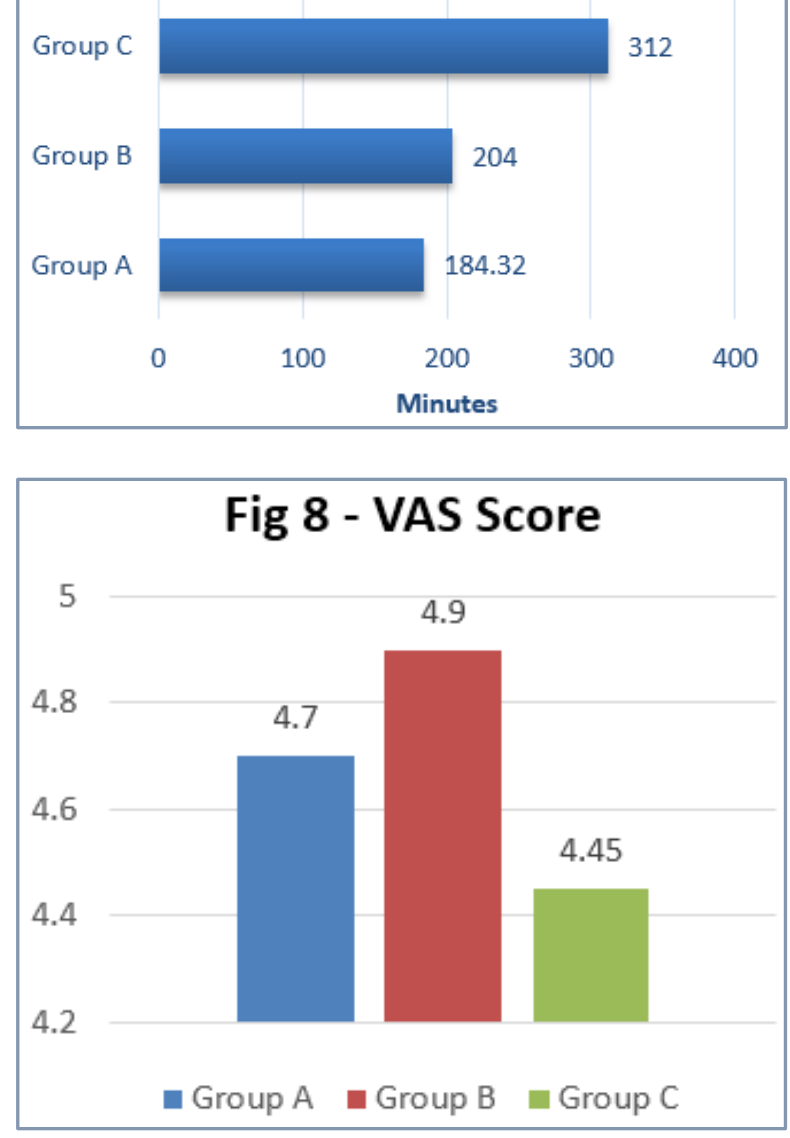

\section{VAS Score}

(Table 8, Figure 8) at the time of pain perception was $4.7 \pm 0.47$ in Group A, 4.9 \pm 1.071 in Group B and $4.45 \pm 0.51$ in Group C. There was no statistically significant difference between the three groups $(\mathrm{p}=0.163)$.

\begin{tabular}{|c|c|c|c|c|}
\hline & Group A & Group B & Group C & P value \\
\hline VAS Score & $4.7 \pm 0.47$ & $4.9 \pm 1.071$ & $4.45 \pm 0.51$ & 0.163 \\
\hline \multicolumn{5}{|c|}{ Table 8: VAS Score } \\
\hline
\end{tabular}

The mean onset time of motor block (Table 9, Figure 9) in Group A is $176.2 \pm 6.95$ seconds, in Group B is $96.9 \pm 19.47$ seconds and in Group C is $113.95 \pm 14.66$ seconds. Onset of motor block was significantly faster with the neostigmine group. There was statistically significant difference between the three groups $(\mathrm{p}<0.0001)$.

The mean duration of motor block (Table 10, Figure 10) was statistically significant in all three groups. Group A $146.16 \pm 20.76$, Group B $176.22 \pm 13.02$ and in Group C it is $252 \pm 13.92$ minutes.

\begin{tabular}{|c|c|c|c|c|}
\hline & Group A & Group B & Group C & $\begin{array}{c}\text { P } \\
\text { value }\end{array}$ \\
\hline Motor & $176.2 \pm$ & $96.9 \pm$ & $113.95 \pm$ & $<0.00$ \\
(Seconds) & 6.95 & 19.47 & 14.66 & 01 \\
\hline \multicolumn{4}{|c|}{ Table 9: Mean Onset of Motor Block } \\
\hline
\end{tabular}

\begin{tabular}{|c|c|c|c|c|}
\hline & Group A & Group B & Group C & P value \\
\hline Motor & \multirow{2}{*}{$146.16 \pm 20.76$} & $176.22 \pm$ & $252 \pm$ & $<0.0001$ \\
Block (Min) & 13.02 & 13.92 & $<$ \\
\hline \multicolumn{4}{|c|}{ Table 10: Mean Duration of Motor Block } \\
\hline
\end{tabular}



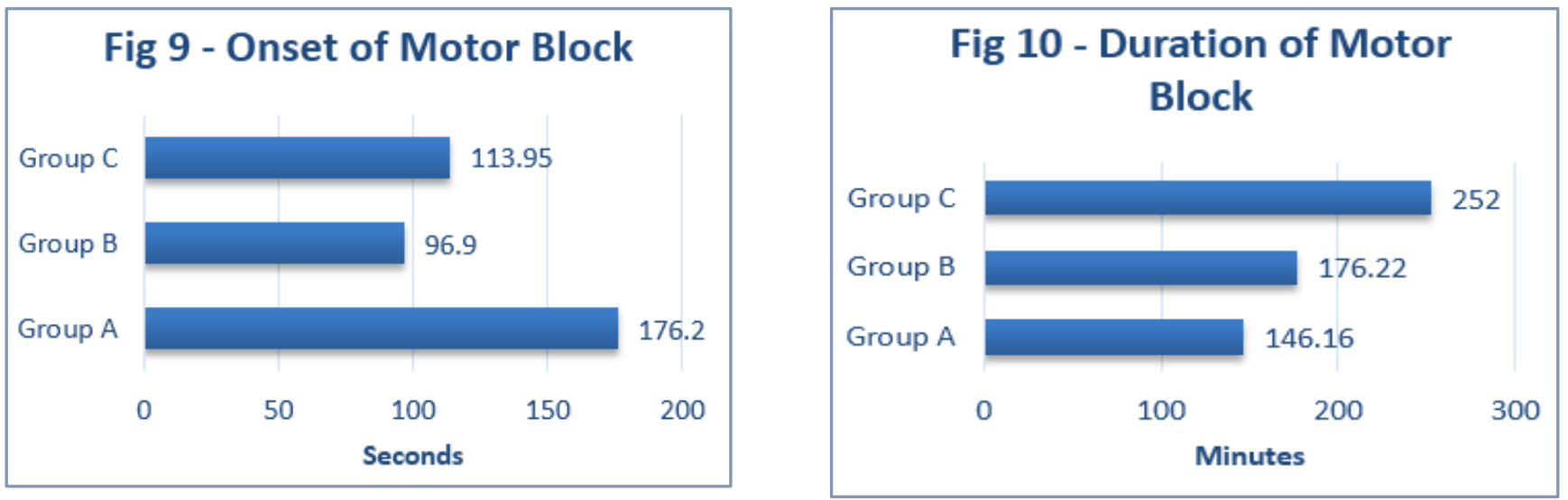

The preoperative heart rate was not statistically significant in the three groups, but heart rates after the tenth minute of spinal anaesthesia were significant statistically. There is a significant drop in the heart rate with the clonidine Group C (Table 11, Figure 11).

\begin{tabular}{|c|c|c|c|c|c|c|c|}
\hline \multirow{2}{*}{ Time } & \multicolumn{2}{|c|}{ Group A } & \multicolumn{2}{|c|}{ Group B } & \multicolumn{2}{|c|}{ Group C } & \multirow{2}{*}{$P$ value } \\
\hline & Mean & SD & Mean & SD & Mean & SD & \\
\hline PR PREOP & 78.9 & 9.968 & 83.5 & 14.468 & 84.55 & 8.947 & 0.256 \\
\hline PR2 & 84.45 & 7.185 & 90.38 & 11.815 & 81.9 & 9.586 & 0.025 \\
\hline PR5 & 82.45 & 8.338 & 88.8 & 11.848 & 75.75 & 9.591 & 0.001 \\
\hline PR10 & 83.05 & 7.366 & 87.3 & 10.006 & 73.15 & 9.366 & 0.0001 \\
\hline PR15 & 84.55 & 9.768 & 83.9 & 12.143 & 71.55 & 8.338 & 0.0001 \\
\hline PR20 & 82.7 & 10.408 & 82.45 & 10.47 & 68.8 & 8.912 & 0.0001 \\
\hline PR25 & 81.1 & 10.809 & 83.15 & 9.778 & 70.3 & 7.02 & 0.0001 \\
\hline PR30 & 81.65 & 10.52 & 81.25 & 8.46 & 69.45 & 6.468 & 0.0001 \\
\hline PR35 & 82.15 & 8.928 & 80.9 & 7.907 & 70.7 & 6.937 & 0.0001 \\
\hline PR40 & 81.15 & 8.061 & 80.55 & 7.38 & 71 & 6.432 & 0.0001 \\
\hline PR45 & 79 & 7.064 & 80.5 & 6.573 & 69.75 & 6.077 & 0.0001 \\
\hline PR50 & 78.45 & 7.395 & 80.7 & 5.639 & 69.2 & 6.144 & 0.0001 \\
\hline PR55 & 77 & 8.105 & 82.05 & 6.1 & 70.25 & 6.64 & 0.0001 \\
\hline PR60 & 79.33 & 9.018 & 81.35 & 4.676 & 72.5 & 5.967 & 0.001 \\
\hline
\end{tabular}

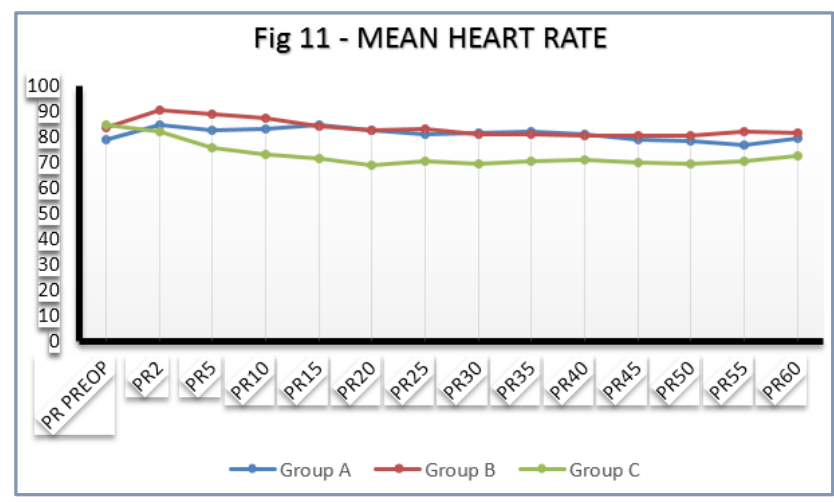

The preoperative systolic BP was not statistically significant in the three groups, but after the tenth minute of spinal anaesthesia the differences were significant statistically. There is a significant drop in the systolic BP with the neostigmine Group B and in the clonidine Group $\mathrm{C}$ when compared to the control Group A (Table 12, Figure 12).

\begin{tabular}{|c|c|c|c|c|c|c|c|}
\hline \multirow{2}{*}{ Time } & \multicolumn{2}{|c|}{ Group A } & \multicolumn{2}{|c|}{ Group B } & \multicolumn{2}{|c|}{ Group C } & \multirow{2}{*}{$P$ value } \\
\hline & Mean & SD & Mean & SD & Mean & SD & \\
\hline PR PREOP & 124.35 & 10.07 & 126.35 & 13.124 & 123.7 & 10.322 & 0.741 \\
\hline PR2 & 122.3 & 8.467 & 124.6 & 11098 & 118.45 & 12.857 & 0.227 \\
\hline PR5 & 118.7 & 8.578 & 122.05 & 10.185 & 114.4 & 12.15 & 0.075 \\
\hline PR10 & 114.15 & 8.887 & 117.35 & 11.061 & 109.2 & 9.099 & 0.035 \\
\hline PR15 & 109.9 & 8.867 & 118.2 & 12.344 & 108.3 & 9.581 & 0.008 \\
\hline
\end{tabular}




\begin{tabular}{|c|c|c|c|c|c|c|c|}
\hline PR20 & 109.45 & 10.4 & 120.85 & 12.214 & 107.3 & 10.204 & 0.0001 \\
\hline PR25 & 109.1 & 12.49 & 120 & 11.734 & 105.95 & 9.73 & 0.0001 \\
\hline PR30 & 111.25 & 13.932 & 120 & 12.439 & 105.95 & 8.029 & 0.0001 \\
\hline PR35 & 113.3 & 12.704 & 120.25 & 12.212 & 106.7 & 8.542 & 0.002 \\
\hline PR40 & 115.75 & 9.797 & 122.65 & 14.694 & 107.55 & 7.373 & 0.001 \\
\hline PR45 & 116.3 & 9.274 & 122 & 12.057 & 108.6 & 7.883 & 0.0001 \\
\hline PR50 & 120.6 & 9.213 & 122.3 & 9.437 & 110.3 & 8.615 & 0.0001 \\
\hline PR55 & 120.7 & 8.682 & 121.75 & 9.657 & 112.2 & 8.667 & 0.002 \\
\hline PR60 & 123.67 & 7.608 & 124.24 & 9.384 & 113.19 & 7.323 & 0.001 \\
\hline
\end{tabular}

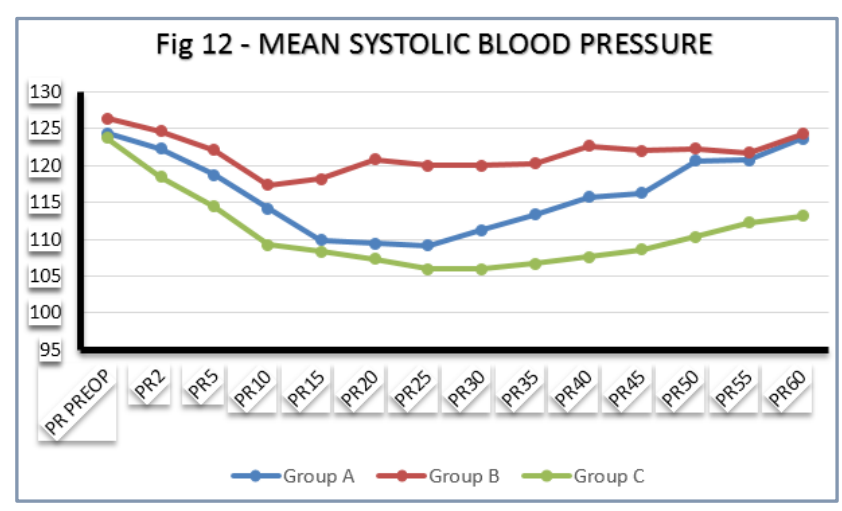

The preoperative diastolic BP was not statistically significant in the three groups, but after the tenth minute of spinal anaesthesia the differences were significant statistically. There is a significant drop in the diastolic BP with the neostigmine Group B and in the clonidine Group C when compared to the control Group A (Table 13, Figure 13).

\begin{tabular}{|c|c|c|c|c|c|c|c|}
\hline \multirow{2}{*}{ Time } & \multicolumn{2}{|c|}{ Group A } & \multicolumn{2}{|c|}{ Group B } & \multicolumn{2}{|c|}{ Group C } & \multirow{2}{*}{$P$ value } \\
\hline & Mean & SD & Mean & SD & Mean & SD & \\
\hline PR PREOP & 80.85 & 6.753 & 78 & 7.567 & 79.5 & 10.185 & 0.558 \\
\hline PR2 & 80.75 & 7.999 & 76.3 & 7.651 & 77.8 & 10.139 & 0.264 \\
\hline PR5 & 77.95 & 6.245 & 76.25 & 6.512 & 72.45 & 12.437 & 0.143 \\
\hline PR10 & 74.55 & 8.062 & 76.85 & 6.201 & 70.1 & 7.704 & 0.018 \\
\hline PR15 & 73.65 & 6.419 & 76.75 & 4.179 & 68.6 & 7.83 & 0.001 \\
\hline PR20 & 72.6 & 5.725 & 76.95 & 2.665 & 68.7 & 8.367 & 0.0001 \\
\hline PR25 & 70.5 & 6.091 & 74.5 & 5.463 & 69.85 & 6.8 & 0.042 \\
\hline PR30 & 71.3 & 5.048 & 73.7 & 5.017 & 68.65 & 5.102 & 0.01 \\
\hline PR35 & 72.9 & 5.647 & 74.05 & 5.605 & 68.75 & 5.28 & 0.009 \\
\hline PR40 & 73.25 & 6.086 & 74.6 & 6.286 & 69.35 & 4.38 & 0.013 \\
\hline PR45 & 75 & 3.92 & 75.65 & 5.412 & 68.65 & 7.088 & 0.0001 \\
\hline PR50 & 76.85 & 4.837 & 75.75 & 5.26 & 70.9 & 7.29 & 0.005 \\
\hline PR55 & 78.65 & 4.095 & 76.9 & 6.078 & 72.65 & 5.234 & 0.002 \\
\hline PR60 & 79.17 & 2.368 & 76.06 & 5.662 & 72.19 & 4.996 & 0.002 \\
\hline \multicolumn{8}{|c|}{ Table 13: Mean Diastolic Blood Pressure } \\
\hline
\end{tabular}

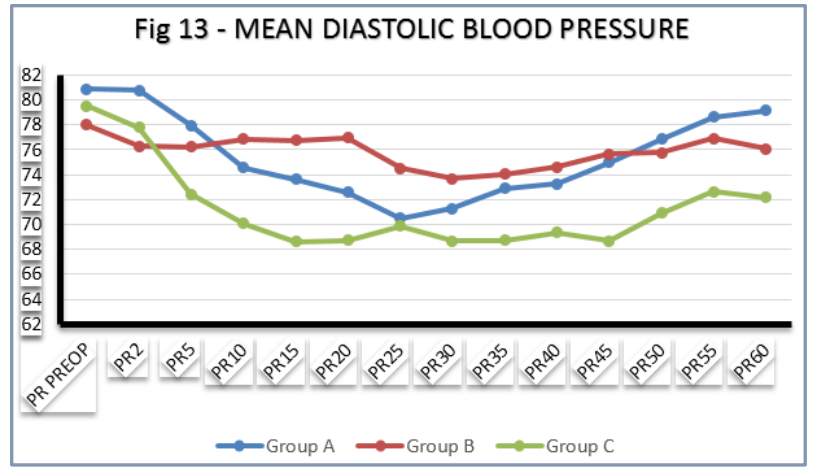

The mean duration of surgery (Table 14, Figure 14) was comparable in all the three groups. The time of completion of surgery was noted following which time for postoperative analgesia was calculated until the time when the patients perceived pain. The postoperative analgesia (Table 15, Figure 15) was $115.7 \pm 20.84$ minutes in Group A, $137.75 \pm 25.46$ minutes in Group B and 245.5 \pm 36.96 minutes in Group C. The duration is prolonged in Groups B and C, but is significantly prolonged in group $\mathrm{C}$ (Clonidine group). 


\begin{tabular}{|c|c|c|c|}
\hline Group & A & B & C \\
\hline $\begin{array}{c}\text { Duration in } \\
\text { Minutes } \\
\text { (Mean } \pm \text { SD) }\end{array}$ & $68.5 \pm 8.217$ & $66.25 \pm 8.416$ & $66.5 \pm 10.336$ \\
\hline \multicolumn{2}{|c|}{ Table 14: Mean Duration of Surgery } \\
\hline
\end{tabular}

\begin{tabular}{|c|c|c|c|c|}
\hline & Group A & Group B & Group C & $\begin{array}{c}\text { P } \\
\text { valu } \\
\text { e }\end{array}$ \\
\hline Postop & $115.7 \pm 2$ & $137.75 \pm 2$ & $245.5 \pm 3$ & 0.00 \\
Analgesia & 0.84 & 5.46 & 6.96 & 01 \\
\hline \multicolumn{2}{|c|}{ Table 15: Duration of Postoperative Analgesia } \\
\hline
\end{tabular}
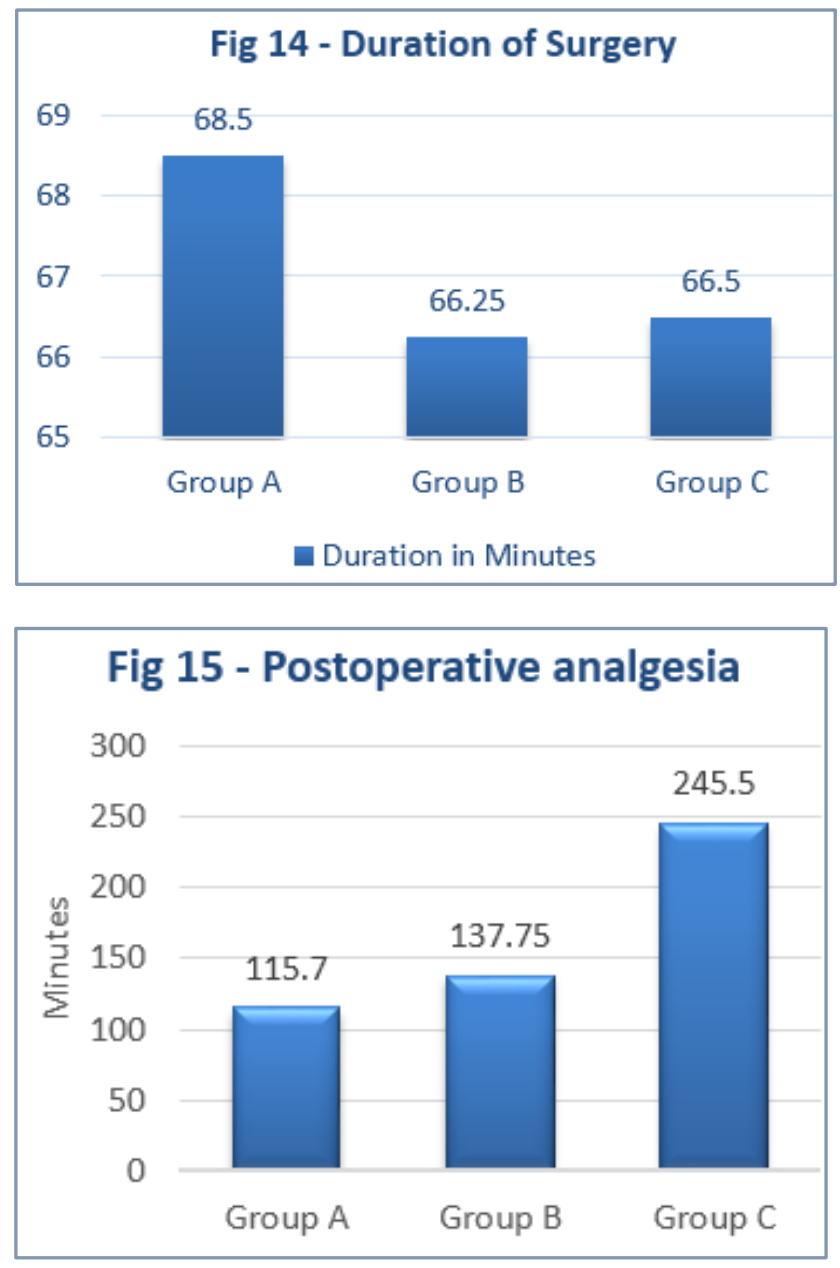

The two segment regression time (Table 16, Figure 16) for the three groups is as follows. In Group A 125.66 \pm 20.56 minutes, Group B $130.458 \pm 32.46$ and in Group C $145.852 \pm 36.58$. There was statistically significant difference between the three groups $(\mathrm{p}<0.0001)$.

\begin{tabular}{|c|c|c|c|c|}
\hline & Group & Group & Group & P \\
A & B & Calue \\
\hline Duration & 125.66 & 130.458 & 145.852 & $<0.0001$ \\
in Minutes & \pm 20.56 & \pm 32.46 & \pm 36.58 & \\
\hline \multicolumn{6}{|c|}{ Table 16: Two Segment Regression Time } \\
\hline
\end{tabular}
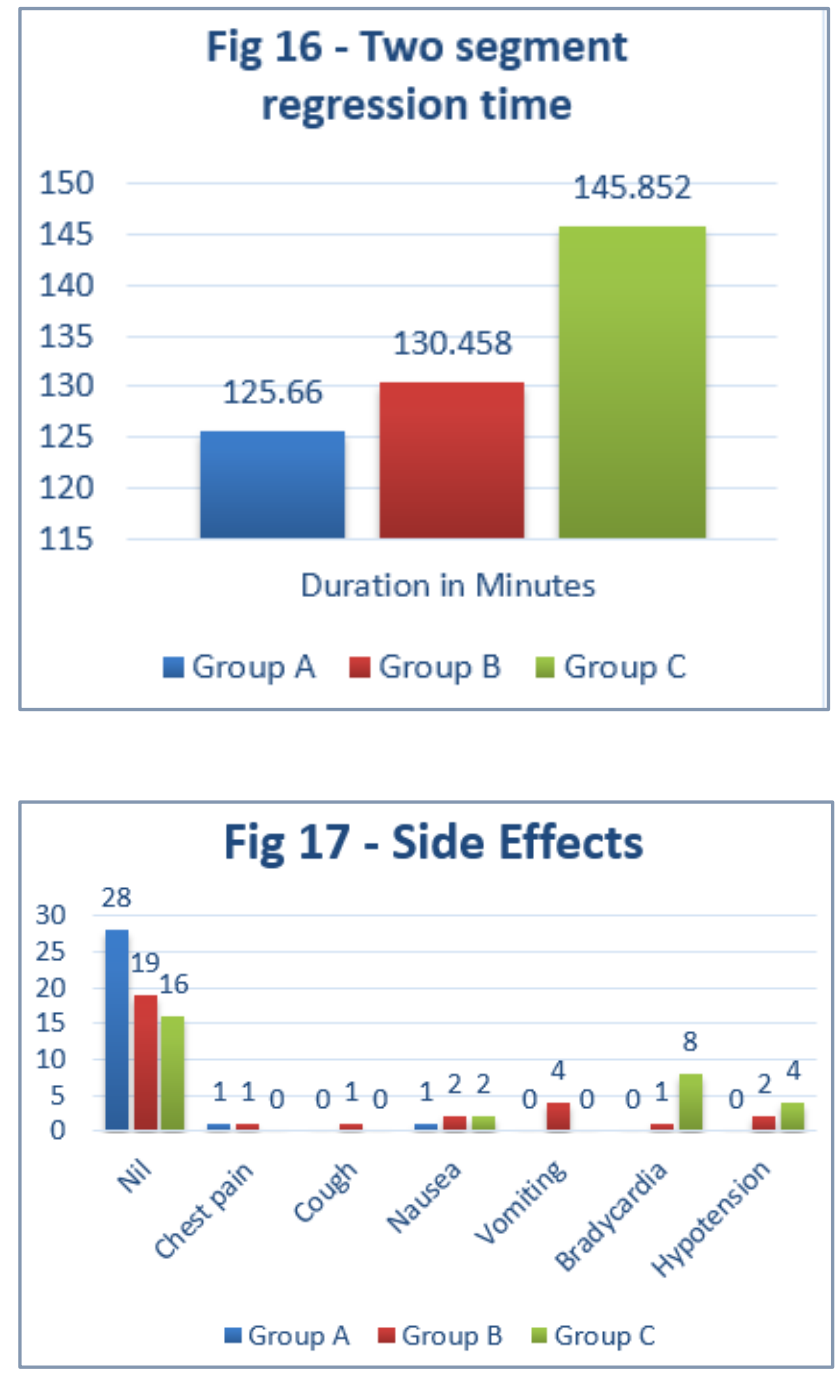

\section{Side Effects}

Chest pain, cough, nausea, vomiting, bradycardia and hypotension were the noted side effects in this study (Table 17, Figure 17). Group A with minimal side effects, Group B with nausea 2 and vomiting 4 and Group $C$ with more incidences of bradycardia 8 and hypotension 4 .

\begin{tabular}{|c|c|c|c|}
\hline Side Effects & Group A & Group B & Group C \\
\hline Nil & 28 & 19 & 16 \\
\hline Chest pain & 1 & 1 & 0 \\
\hline Cough & 0 & 1 & 0 \\
\hline Nausea & 1 & 2 & 2 \\
\hline Vomiting & 0 & 4 & 0 \\
\hline Bradycardia & 0 & 1 & 8 \\
\hline Hypotension & 0 & 2 & 4 \\
\hline \multicolumn{4}{|c|}{ Table 17: Side Effects } \\
\hline
\end{tabular}

Intrathecal Neostigmine group produces faster onset of motor and sensory blockade, longer duration of motor as well as sensory block compared to the control group. Intrathecal Clonidine group produces considerable longer duration of motor block and sensory block when compared to the control and the neostigmine groups. At the same time intrathecal clonidine produces more incidences of hypotension and bradycardia. 


\section{DISCUSSION}

Lower limb surgeries and lower abdominal surgeries like hernioplasty, appendicectomy and abdominal hysterectomies are performed under spinal anaesthesia, as it is easy to perform, single shot technique when compared to epidural and general anaesthesia. But its main drawback is that the analgesia is of limited duration. Hence, additives which cause the prolongation of the duration of motor as well as sensory block will be beneficial in reducing the morbidity of the patients in the postoperative period.

This study was performed to compare the effects of adjuvants neostigmine and clonidine along with $0.5 \%$ hyperbaric bupivacaine for spinal anaesthesia.

Akinwale MO. ${ }^{1}$ et al showed that spinal neostigmine $25 \mu \mathrm{g}$ added to hyperbaric bupivacaine and fentanyl provided a significantly longer surgical analgesia and insignificant adverse effects in male adults who had lower abdominal surgery under spinal anaesthesia. Pan PM. ${ }^{2}$, Huang CT, Wei TT, Mok MS in 1998 found that the onset of sensory block was rapid in neostigmine group than the clonidine group in caesarean patients.

Yoganarasimha. ${ }^{3}$ and co-worker in 2014 also found that the onset of sensory and motor block was faster in neostigmine when compared to clonidine.

Elia. ${ }^{4}$ et al found that the two segment regression time, delay in regression time to $\mathrm{L} 2$, time needed for the first rescue analgesia and motor block was extended with Intrathecal clonidine. They also found that there is an increased incidence of arterial hypotension.

Andrieu. ${ }^{5}$ et al in 2004 found significant reduction in morphine requirement during the first 48 postoperative hours after a radical prostatectomy. The addition of clonidine to intrathecal morphine reduced intraoperative sufentanil use, prolonged time until first request for PCA rescue and further prolonged analgesia at rest and with coughing.

Strebel. ${ }^{6}$ et al in 2004 studied the effect of different doses $(37.5,75$ and $150 \mu \mathrm{g})$ of clonidine and conclude that small doses of intrathecal clonidine $(\leq 150 \mu \mathrm{g})$ significantly prolong the anaesthetic and analgesic effects of bupivacaine in a dosedependent manner.

Kanazi. ${ }^{7}$ et al in 2006 showed that the patients added $\alpha-2$ agonists with spinal bupivacaine had rapid onset time of motor block and took longer time for sensory and motor regression.

Marrivirta. ${ }^{8}$ et al 2010 found prolongation of motor block in patients who received intrathecal clonidine. They also showed that there is more vasopressor requirement and less postoperative pain.

Rochette. ${ }^{9}$ et al demonstrates that clonidine $1 \mu \mathrm{g} / \mathrm{kg}$ doubles neonatal spinal anaesthesia duration without providing undesirable haemodynamic effects in the immediate postoperative period.

De Kock M. ${ }^{10}$ et al showed that a small-dose of intrathecal clonidine $(15 \mu \mathrm{g})$ plus $8 \mathrm{mg}$ intrathecal ropivacaine produces adequate and short-lasting anaesthesia for knee arthroscopy.

Dobrydnjov I et $\mathrm{al}^{11}$ found that the addition of clonidine 15 micro $g$ to $6 \mathrm{mg}$ of hyperbaric bupivacaine increases the spread of analgesia, prolongs the time to first analgesic request and decreases postoperative pain compared with bupivacaine alone during inguinal herniorrhaphy under spinal anaesthesia. They also compared intrathecal clonidine and oral clonidine and found that addition of intrathecal clonidine prolonged analgesia and decreased morphine consumption postoperatively more than oral clonidine. ${ }^{12}$ Hypotension was more pronounced after oral than after intrathecal clonidine. Intrathecal clonidine is therefore recommended.

Sethi BS et al ${ }^{13}$ study has demonstrated that addition of clonidine to bupivacaine in the dose of $1 \mu \mathrm{g} / \mathrm{kg}$ significantly increases the duration of analgesia following its placement in subarachnoid space as compared to bupivacaine alone.

Gupta S.14 observed enhanced analgesia by intrathecal neostigmine in $75 \mu \mathrm{g}$ dose as is shown by less consumption of intramuscular diclofenac sodium.

Liu SS et al ${ }^{15}$ showed that the addition of $50 \mu \mathrm{g}$ neostigmine prolonged the duration of sensory and motor block.

\section{CONCLUSION}

This study concludes that the addition of neostigmine to $0.5 \%$ hyperbaric bupivacaine intrathecal hastens the onset of sensory block. It also prolongs the duration of sensory and motor block when compared to $0.5 \%$ hyperbaric bupivacaine alone.

Adding clonidine to $0.5 \%$ hyperbaric bupivacaine intrathecal significantly prolongs the duration of motor as well as sensory block when compared to bupivacaine alone and the neostigmine groups. Intrathecal clonidine is a better choice for prolonging the duration of postoperative analgesia of $0.5 \%$ hyperbaric bupivacaine.

\section{ACKNOWLEDGEMENT}

We are very grateful to the professors and assistant professors of the Department of General Surgery, Orthopaedics and Obstetrics and Gynaecology.

We are extremely thankful to the assistant professors and the postgraduates of the Department of Anaesthesiology for their help in carrying out this study.

We are thankful to the Institutional Ethical Committee for their guidance and approval for this study. Last but not the least, we thank all our patients for willingly submitting themselves for this study.

We also wish to state that no financial or material support was obtained for this study.

\section{REFERENCES}

1. Akinwale MO, Sotunmbi PT, Akinyemi OA. Analgesic effect of intrathecal neostigmine combined with bupivacaine and fentanyl. Afr J Med Med Sci 2012;41(2):231-7.

2. Pan PM, Huang CT, Wei TT, et al. Enhancement of analgesic effect of intrathecal neostigmine and clonidine on bupivacaine spinal anaesthesia. Reg Anaesth Pain Med 1998;23(1):49-56.

3. Yoganarasimha N, Raghavendra TR, Amitha S, et al. A comparative study between intrathecal clonidine and neostigmine with intrathecal bupivacaine for lower abdominal surgeries. Indian Journal of Anaesthesia 2014;58(1):43-7.

4. Elia N, Culebras X, Mazza C, et al. Clonidine as an adjuvant to intrathecal local anaesthetics for surgery: systematic review of randomized trials. Reg Anaesth Pain Med 2008;33(2):159-67.

5. Andrieu G, Roth B, Ousmane L, et al. The efficacy of intrathecal morphine with or without clonidine for postoperative analgesia after radical prostatectomy. Anesth Analg 2009;108(6):1954-7. 
6. Strebel S, Gurzeler JA, Schneider MC, et al. Small-dose intrathecal clonidine and isobaric bupivacaine for orthopedic surgery: a dose-response study. Anesth Analg 2004;99(4):1231-8.

7. Kanazi GE, Aouad MT, Jabbour-Khoury SI, et al. Effect of low-dose dexmedetomidine or clonidine on the characteristics of bupivacaine spinal block. Acta Anaesthesiol Scand 2006;50(2):222-7.

8. Merivirta R, Kuusniemi K, Jaakkola $\mathrm{P}$, et al. Unilateral spinal anaesthesia for outpatient surgery: a comparison between hyperbaric bupivacaine and bupivacaineclonidine combination. Acta Anaesthesiologica Scandinavica 2009;53(6):788-93.

9. Rochette A, Raux $\mathrm{O}$, Troncin $\mathrm{R}$, et al. Clonidine prolongs spinal anesthesia in newborns: a prospective doseranging study. Anesth Analg 2004;98(1):56-9.

10. De Kock M, Gautier P, Fanard L, et al. Intrathecal ropivacaine and clonidine for ambulatory knee arthroscopy: a dose-response study. Anesthesiology 2001;94(4):574-8.
11. Dobrydnjov I, Axelsson K, Samarütel J, et al. Postoperative pain relief following intrathecal bupivacaine combined with intrathecal or oral clonidine. Acta Anaesthesiol Scand 2002;46(7):806-14.

12. Dobrydnjov I, Axelsson K, Thörn SE, et al. Clonidine combined with small-dose bupivacaine during spinal anesthesia for inguinal herniorrhaphy: a randomized double-blinded study. Anesth Analg 2003;96(5):1496503.

13. Sethi BS, Samuel M, Sreevastava D. Efficacy of analgesic effects of low dose intrathecal clonidine as adjuvant to bupivacaine. Indian J Anaesth 2007;51(5):415-9.

14. Gupta S. Postoperative analgesia with intrathecal neostigmine; two different doses of $75 \mu \mathrm{gms}$ and 50 $\mu \mathrm{gms}$ with heavy bupivacaine. The Internet Journal of Anaesthesiology 2009;25(1).

15. Liu SS, Hodgson PS, Moore JM, et al. Dose-response effects of spinal neostigmine added to bupivacaine spinal anesthesia in volunteers. Anesthesiology 1999;90(3):710-7. 